\title{
Lessons from environmental and social sustainability certification standards for equitable REDD+ benefit-sharing mechanisms
}

\author{
Januarti Sinarra Tjajadi, Anastasia Lucy Yang, Daisuke Naito and Shintia Dian Arwida
}

\section{Key Lessons}

- If REDD+ benefit-sharing mechanisms (BSMs) are to be equitable, they require clear objectives with appropriate strategies or indicators. Private sector schemes related to standards, whose objective is the equitable distribution of the benefits generated through certification, tend to lack adequate rules and guidelines for operationalizing an equitable benefitsharing process.

- At the local level, support and capacity building are needed to strengthen intermediary institutions in order to improve governance and increase legitimacy when deciding how to share benefits.

- Systematic measures for identifying marginalized groups and supporting their greater participation in the design, implementation and monitoring of BSMs can help to avoid perpetuating existing inequities.

- A minimum price-setting mechanism established between buyers and sellers will consider the overall implementation costs of standards and help mitigate farmer risks. A thorough consideration, accounting and attribution of REDD+ costs is essential as a basis for price setting to ensure that suppliers of reduced carbon emissions are compensated for the costs they bear.

- The inclusion of pre-financing enables participation of poor stakeholders in implementation activities, helps to mitigate market and other risks incurred by the participating smallholders and raises acceptance of the standards. Phased-released benefits that are maintained throughout the project lifetime strengthen conformity to conditional performance.

- Equity requirements can come with higher transaction and implementation costs. A place-based policy that aims to achieve equity to adjust for changing contexts while maintaining accountability should be considered as a way of reconciling equity and efficiency.

\section{Introduction}

The notion of benefit sharing - the distribution of direct and indirect net gains from the implementation of an activity - is not exclusive to REDD+. Natural resource sectors such as agriculture and forestry have accumulated years of experience in the design and implementation of benefitsharing mechanisms (BSMs) (Rosendal 2010; Costenbader 2011; Assembe-Mvondo et al. 2013). Environmental and social sustainability is usually facilitated across these sectors by global private-sector certification standards. To identify lessons from such standards for benefit sharing under REDD+, we reviewed the design and impacts of certification standards, particularly those that seek to achieve sustainable management of natural resources and delivery of social benefits.

We reviewed four certification standards: Climate, Community \& Biodiversity (CCB), Plan Vivo, Fairtrade for Small Producer Organizations (SPO) and Forest Stewardship Council (FSC) for large-scale forestry operations. We selected these standards from a pool of 30 schemes across several sectors as they all included requirements for benefit sharing and had impact data available. We also drew on insights from the Participatory Guarantee System (PGS), which is an alternative option for third-party certification endorsed by International Federation of Organic Agriculture Movements (IFOAM). An overview of the four standards and PGS are presented in Table 1.

Here we aim to: analyze the design features of the BSM of the different selected standards at the local level, and use the experiences and lessons for the development of REDD+. This brief is not an exhaustive comparison between the standards but an assessment of benefit sharing between the relevant local beneficiaries, across the dimensions of procedural, contextual and distributive equity. According to McDermott et al. (2013) "procedural" equity refers to the decision-making processes; "contextual" to overall capacities of relevant stakeholders to participate, access, and capture benefits; and "distributive" on how costs, benefits and risks are distributed. 

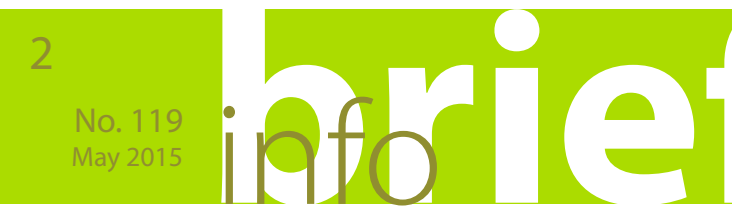
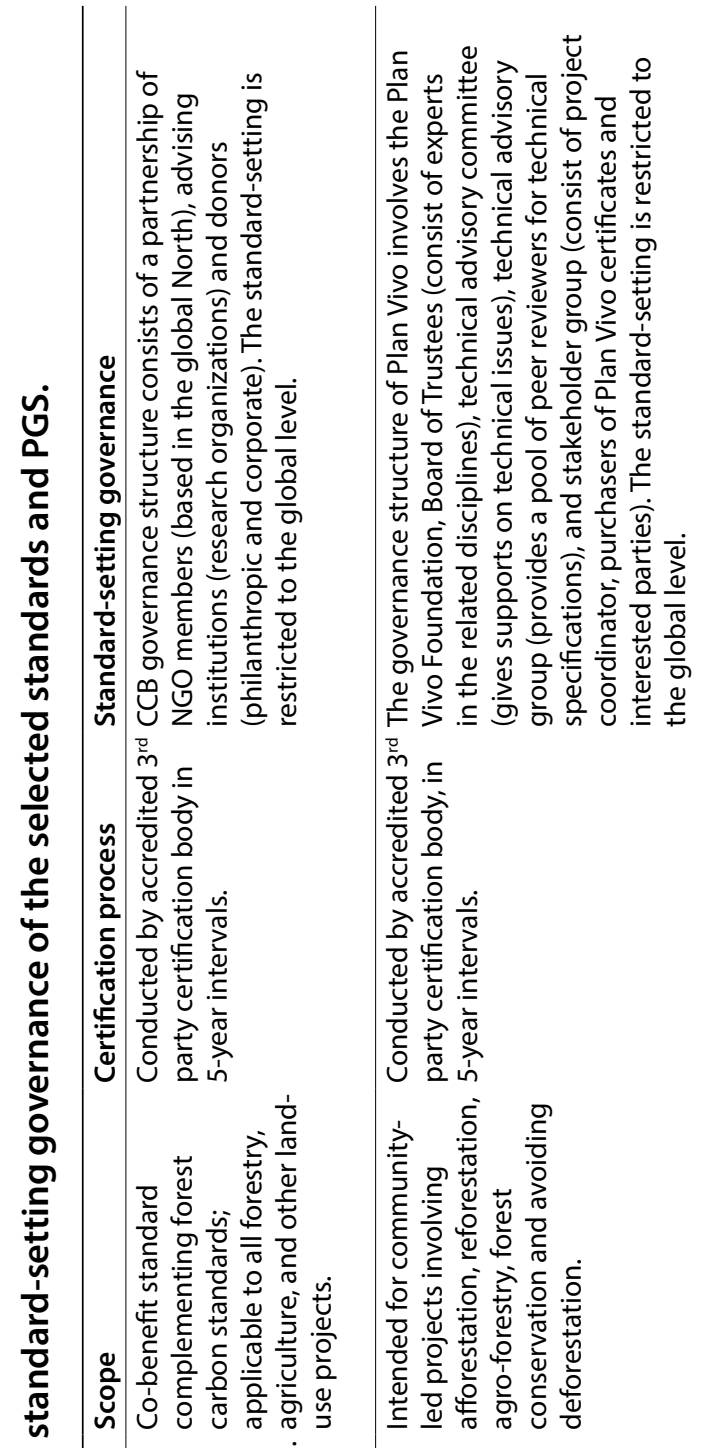

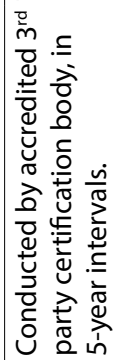

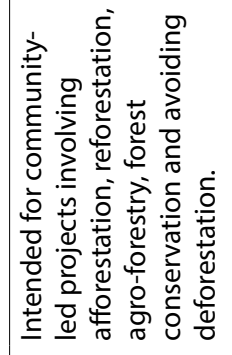

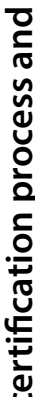

(2)

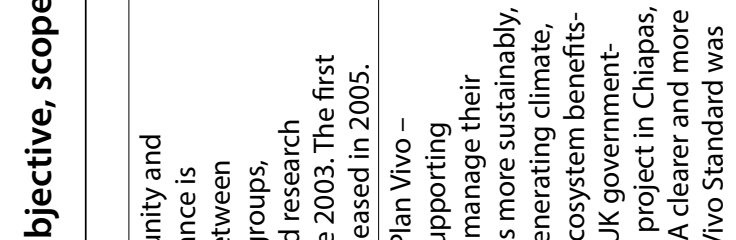

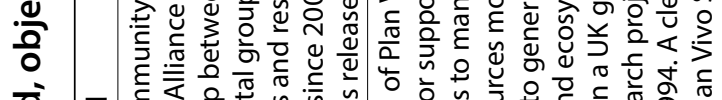

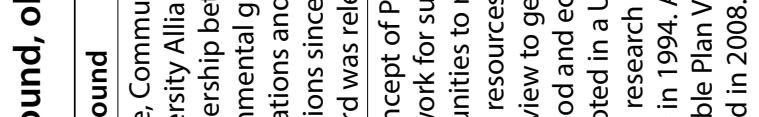

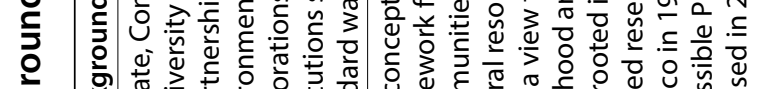

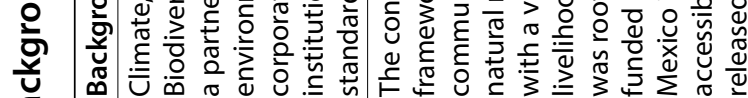

离

产

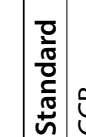

$\underset{\substack{\frac{c}{0} \\ \frac{c}{2}}}{\frac{2}{2}}$

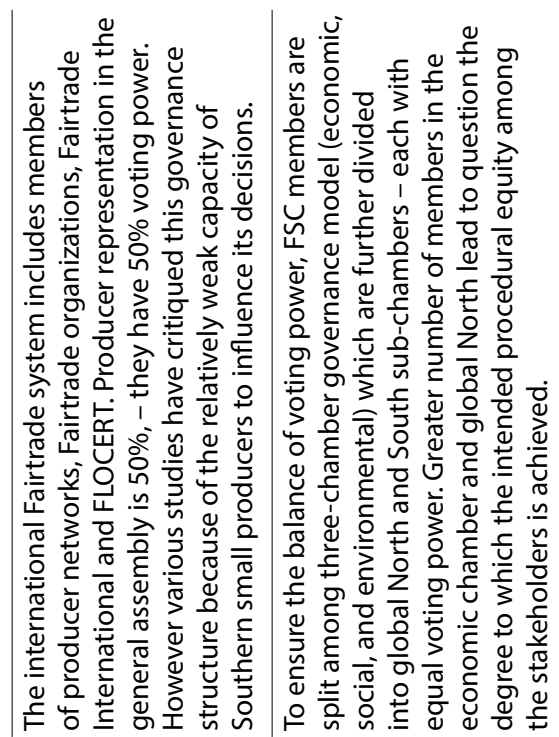

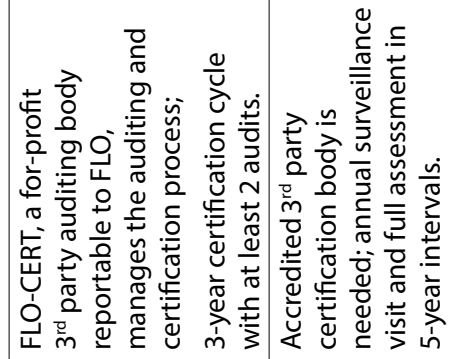

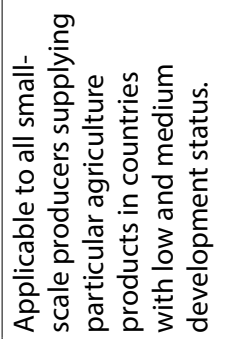

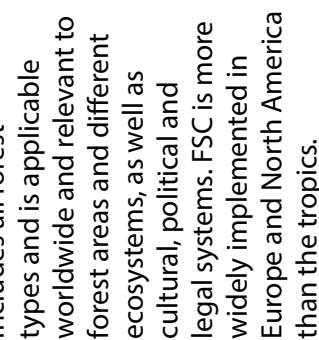

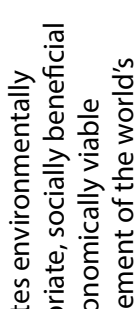

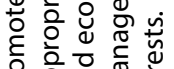

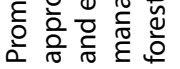

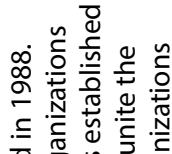

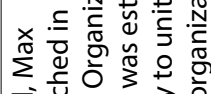

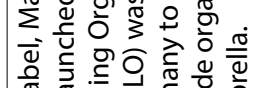

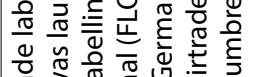

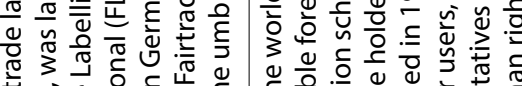

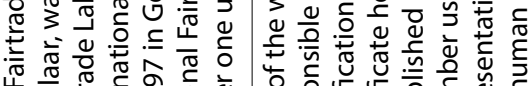

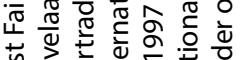

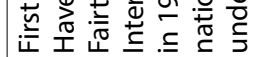

호

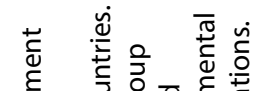

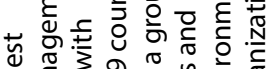
年

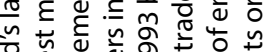

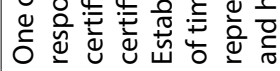

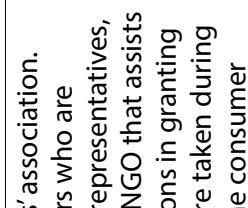

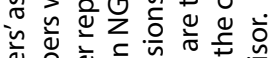

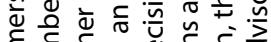
홍 ㅎํ

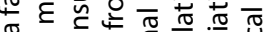

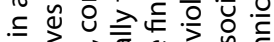

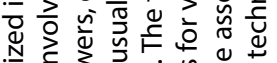

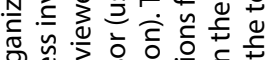

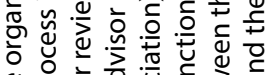

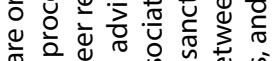
๙

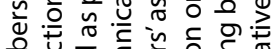

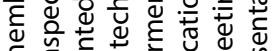

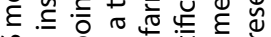

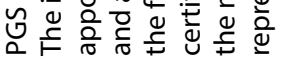

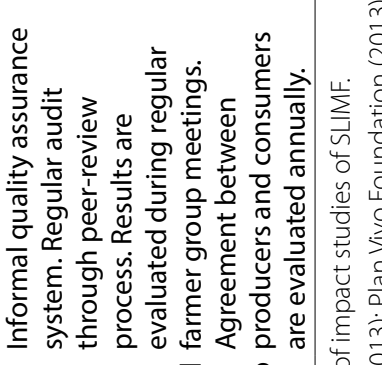
늘

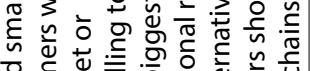

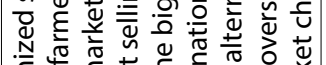
宁 艺

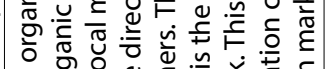

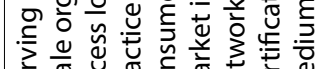

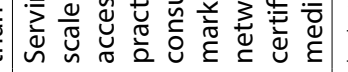

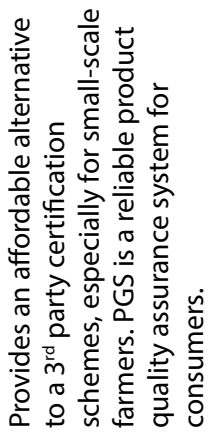

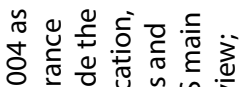

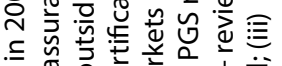

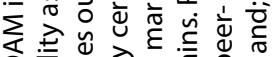

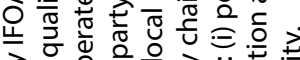

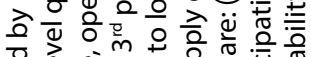
议

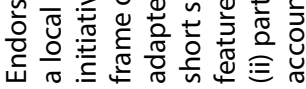


This equity framework was used as a basis for this study as all the standards reviewed attempted to have "fair" and/ or "equitable" benefit- and/or cost-sharing outcomes. For procedural aspects, we aim to understand if the process of decision-making about benefit distribution was equitable at the local level. This includes identifying how the reviewed standards and PGS addressed participation in the process of defining size, timing and type of benefits and the decision of who should get benefits. In addition, we aim to identify if the standards provided dispute resolution procedures. Contextual equity includes capacity-building measures and clarification of tenure rights that may enhance marginalized actors' ability to participate. Lastly, distributive equity reflects the outcomes of the distribution mechanism endorsed by those standards in how the benefits and the costs are shared between producers and managers or buyers. The following discussion is framed on how the standards address equitable benefit sharing across the three equity dimensions. The lessons for REDD+ are drawn from this assessment.

\section{Standards and equitable benefit- sharing mechanism}

BSM in the context of REDD+ refers to the variety of institutional means, governance structures and instruments for the distribution of finance and other net benefits from REDD+ programs (Vhugen et al. 2011; Luttrell et al. 2013). Therefore we also consider non-monetary benefits derived from the standards such as enhanced governance, rights and tenure security and capacities. When defining benefits it is necessary to take costs into account, because it is the net gains that matter, i.e. benefits provided minus costs incurred (Luttrell et al. 2013). This paper also aims to identify any design features promoted by the standards in ensuring the delivery of monetary net benefits. Each standard incorporates the three equity dimensions into their design, with varying measures (Table 2). The following results and discussions explore the strengths and limitations, and the varying extents of each standards attempt to promote equitable benefit- and cost-sharing.

\subsection{Procedural equity}

\subsubsection{Stakeholder identification}

McDermott et al. $(2013,420)$ describes procedural equity as the "meaningful public participation [that] requires recognition of all parties and affirmative efforts to ensure their inclusion and representation" in decision-making. The standards vary in their emphasis on 'who' is considered as a stakeholder and consequently 'who' is to be incorporated in the participatory process. In the case of Plan Vivo, Fairtrade for SPO' and PGS, the focus is on the participating producers within the project rather than those outside the project. FSC encourages the participation of affected stakeholders,

Written as Fairtrade onward in this paper for example, stakeholders in the neighborhood of the management activities. However each stakeholder, whether involved in the project or not, should have a voice in the process to limit any potential harm that might occur (ShraderFrechette 2002; McDermott et al. 2013).

This issue is best captured by the CCB standards which set requirements for project developers to conduct stakeholder identification and analysis, and document efforts to ensure all relevant stakeholders can participate accordingly (CCBA 2013). CCB differentiates between "communities"2 and "other stakeholders" 3 and each identified group is entitled to varying degrees of participation. Both communities and other stakeholders have rights to access full information and influence project design and implementation through consultation, but only communities can participate in decision-making and implementation (CCBA 2013). Although CCB and FSC require stakeholder identification, these procedures are essentially nonmandatory guidelines, and are not part of the standards against which projects are evaluated. Thus, there is no assessment of whether or not this process is implemented (Colchester et al. 2003; Eklöf 2013).

CCB, Plan Vivo and FSC standards require a "free prior and informed consent" (FPIC) ${ }^{4}$ process. The targeted stakeholder in the CCB FPIC process are property rights holders, both customary and statutory; for Plan Vivo, it is the participating smallholders; and for FSC, it is the affected indigenous people and local communities. A qualitative review of the early outcomes from 41 REDD+ projects, validated by CCB $2^{\text {nd }}$ edition and Plan Vivo 2008 version reveals that projects require more practical guidance on how to obtain and sustain FPIC (Lawlor et al. 2013). This study shows that a clear concept in terms of type and objective of participation, coupled with more specific criteria on how this might be achieved, is important to make it work in practice as intended. Overall, FSC has established the most clearly described FPIC guideline among the standards reviewed, specifying explicitly what actions are needed to obtain and maintain FPIC (FSC 2012b).

2 CCB defines 'communities' as all groups of people (including indigenous people, mobile peoples and other local communities) who derive income, livelihood or cultural values and other contributions to well-being from the project area at the start of the project and/or under the with-project scenario. Sub-groups of 'communities' are 'community groups', such as indigenous peoples, women, youth or other social, cultural and economic groups.

3 CCB defines 'other stakeholders' as all groups other than communities who can potentially affect or be affected by the project activities and who may live within or outside the project zone.

4 FPIC principles were first formally laid out by the 1989 International Labour Organization's (ILO) Convention on Indigenous and Tribal Peoples in Independent Countries (ILO 169). Then the concept was strongly reinforced by the 2007 United Nations Declaration on the Rights of Indigenous Peoples (UNDRIP), which outlined a host of scenarios in which FPIC should become the standard "best practice" for negotiation between indigenous peoples and any other entity. 


\subsubsection{Ensuring active participation}

Marginalized groups must be included to ensure the participation processes serve to maintain equality among stakeholders rather than perpetuating power imbalances (Amerasinghe et al. 2008). A perceived "just process" can increase a sense of ownership and commitment to support, implement and monitor decisions, thus enhancing the overall effectiveness of an intervention (Earle and Malzbender 2006; Sommerville et al. 2010).

In practice, participation can be limited to simply sharing information, or can lead to the transfer of power and control (Pimbert and Pretty 1995; Gebara 2013). All the standards reviewed address participation to differing degrees. Fairtrade, Plan Vivo and PGS require active participation and ownership of activities by producers (Table 2). In these three standards, participating farmers can form a local governance structure, which takes a lead role in developing and implementing their management plan to comply with the standards.

Fairtrade has further developed descriptive criteria to achieve this goal. It reinforces procedural equity through the empowerment of local governance structures, and follows the International Labour Organization (ILO) recommendations on the promotion of cooperatives that prescribes general rules for democracy, participation and transparency (Fairtrade International 2011). Among these rules is the establishment of a general assembly (the highest decision-making body) consisting of all cooperative members and/or elected delegates, that must be held at least once a year; all motions are decided through majority vote; and there are bookkeeping practices requirements (Fairtrade International 2011). These requirements have enhanced democratic community decision-making processes between the producers (Appendix 1) (Le Mare 2008; Smith 2010). Yet, arguably the Fairtrade approach does not address the power dynamics within the cooperation where more literate actors are selected for the management level, who may then dominate the decision-making process (Berndt 2007; Utting 2009).

A naive assumption that is common in the context of REDD+ is that the distribution of benefits to community organizations as local intermediaries will have a trickle-down effect, with the benefits reaching all community members, including marginalized groups. However, this assumption ignores the power dynamics embedded in a community's culture and social structure (Setyowati 2012). It is therefore important to have in place mandatory systematic measures for identifying marginalized groups and for supporting their participation in the design, implementation and monitoring of REDD+ activities and the BSM. If such measures are not introduced, REDD+ risks perpetuating existing exclusions and inequalities, compromising the initiative's overall effectiveness. All the selected standards require projects to address the inclusion of marginalized groups in the participatory process, with variations in the required scope. Plan Vivo, CCB and Fairtrade explicitly require projects to demonstrate measures to identify disadvantaged producers (e.g. according to gender, age, socioeconomic status, ethnicity or religion) and to develop measures to encourage participation of those who experience barriers in their design and implementation (Fairtrade International 2011; CCBA 2013; Plan Vivo Foundation 2013).

\subsubsection{Dispute resolution mechanisms}

REDD+ activities can have direct impacts at the local level (e.g. land tenure conflict, access to resources, or insufficient payments), thus it is essential to have a legitimate and effective dispute resolution mechanism to resolve disagreement among stakeholders and improve outcomes. Fairtrade, Plan Vivo, CCB and PGS also promote legitimate local entities in the communities, such as producer's organizations or project managers, to receive, respond to and resolve disputes informally at the initial implementation stages. For example in PGS, the dispute resolution process is conducted through regular, informal meetings with disagreements mainly related to payment and product quality issues. The role of farmers is acknowledged as important in the resolution process as representatives of small producers (personal communication from members of PGS for Indonesia [PAMOR], February 2013). Similarly for FSC, local institutions and forest operators in the Congo Basin regularly discuss issues related to benefit-sharing (e.g. insufficient funding, failure in maintaining agreements) (Cerutti et al. 2014). The CCB's recognition of traditional methods that local stakeholders use to mediate and even solve their disputes holds a lesson for REDD+. Blomley and Richards (2011) stated that disputes can be more effectively managed through traditional or customary conflict resolution mechanisms when courts had a limited capacity to process claims or unable to have enforce those decisions.

FSC provides a formal, independent and well-structured dispute resolution mechanism that could potentially be adopted at various levels for REDD+. Following several controversial cases on forest certification, the new 'FSC Dispute Resolution System' guidelines launched in 2009 offer improvements in terms of accessibility, transparency, timeliness and efficacy compared to the previous guidelines (Marx et al. 2012). FSC created the Accreditation Services International (ASI), an independent body, which authorizes and monitors the certification body and FSC. Stakeholders with concerns about a certificate holder should contact the certificate holder directly (FSC 2009). If the problem cannot be solved, the stakeholder can contact the certification body, FSC or ASI. A time-bound dispute resolution procedures and a web-based mechanism for FSC was also established for stakeholders to submit and track complaints and appeals as a way of facilitating transparency. From case studies conducted in Brazil, Indonesia and Malaysia, it was found that these dispute resolution procedures between forest operators and local communities also led to the establishment of clearer land tenure rights (Simula et al. 2004). 
The role of intermediaries is important to ensure that complaints, irrespective of stakeholders' circumstances, can be received by management because formal procedures may act as a barrier to local and indigenous groups, depending on the available means for communication (Colchester et al. 2003). REDD+ initiatives should establish clearly written and avoid legally complex procedures (i.e. using legal terms, cross-referred clauses) making the process more accessible to non-expert use, especially to local individuals and small organizations (Counsell and Terje Loraas 2002).

In summary, the endorsement of procedural equity by each of the standards has provided useful insights for REDD+. Participation should be clearly defined in terms of level of involvement (i.e. FPIC, access to information, consultation, participation in decision-making and implementation) and objective (e.g. mitigate possible negative impact, improve livelihood) to certain groups of stakeholders. This should be followed by a specific set of measures needed to achieve, monitor and assess participation to ensure procedural equity on the ground. However, more stringent procedural equity requirements potentially lead to higher transaction and implementation costs thus creating an inevitable trade-off between equity and efficiency. For example, in the Fairtrade context, where local institution empowerment is emphasized, some argue these efforts are too costly in part because the cooperative structure is dependent on an expensive topheavy entrepreneurial hierarchy with a large administrative staff, which demands increased bureaucracy with higher requirements for accountability (Mendoza and Bastiaensen 2003; Berndt 2007; Yang et al. 2014).

An appropriate balance between equity and efficiency objectives must be established to ensure optimal effectiveness and the long-term sustainability of the initiative. Avoiding fixed systems and giving local authorities the necessary flexibility to adjust for spatially and temporally changing contexts can contribute to achieving this balance, as long as accountability is not jeopardized (Dyer et al. 2012). The FSC standards recognize the contextual variations and provides flexibility through the concept of "scale, intensity and risk", meaning that compliance with the standards can differ depending on the scale and intensity of forest operator activities, and on the risk of negative impacts (FSC 2012a). This has the advantage of allowing case-specific measures that are tailored for each situation, but more guidance is needed to promote the effective application of this concept (Synnott 2012).

\subsection{Contextual equity}

Different capacities, such as education and political recognition in resource allocation can influence procedural and distributive equity and shape people's access to resources (McDermott et al. 2011). Thus, we focus on how standards content deals with stakeholders existing capacities to improve their entitlement to the benefits delivered. In this subsection, we categorized FPIC as an indicator for contextual equity when it is used as a tool to recognize and clarify land tenure (McDermott 2013). In most of the standards, contextual equity is addressed through capacity building and recognition of tenure rights (Table 2).

Requirements for resource ownership are explicit in FSC, CCB and Plan Vivo standards. There is some evidence FSC has helped facilitate indigenous people in negotiating and securing their resource rights through FPIC (Taylor 2005; McDermott 2013; Cerutti et al. 2014). For Plan Vivo certification, clear land tenure is a precondition to participate in the initiative. Therefore, one of the roles of Plan Vivo project coordinators is to assist participants in showing that they have the rights to transact ecosystem services, make decisions and implement land-use activities in the long term (Plan Vivo Foundation 2012). It was evident that some Plan Vivo projects helped participating local people gain land ownership and management rights (Lawlor et al. 2013). However, those who were unable to demonstrate their tenure rights (e.g. landless people) could not participate, which may further exacerbate existing inequalities (Schreckenberg 2012).

An interesting key feature of PGS is that producers are also engaged in capacity-building processes (May 2008). Farmers can learn from colleagues' experiences during the peer review process and during discussions in meetings. However, compared to the other standards, Fairtrade is the most prescriptive on how to actively enhance capacity development, demonstrated via the so-called Fairtrade Development Plan - a work plan for the SPO to highlight opportunities for the farmers to pursue their development in line with their needs. Organizational development has been emphasized as a core component of Fairtrade and there is evidence for success in this aspect. Benefits identified by certified farmers include increased organizational skills, enhancing attainment of more equitable trade, distributing sales payment, and social benefits among its members (FAO 2003; Walsh 2004; Ruben and Fort 2012).

For REDD+, the key contextual equity concerns center on access to resources and social exclusion from decisionmaking process that can each compromise distributional equity as a consequence (Di Gregorio et al. 2013; Gebara 2013). Insights from the standards efforts in recognizing and establishing tenure rights indicate that proper implementation of FPIC processes, which has become a central principle of REDD+ social safeguards, can increase actors' capacities to negotiate and secure local rights to resources. These negotiation capacities are essential for smallholders participation in decision-making and to understand and accept BSM. Therefore it is crucial to understand diverse tenure arrangements and specific realities in REDD+ project contexts before they are designed (Howard et al. 2015). Measures to improve capacity of the local institutions in order to enable increasing roles of project management 
are important to ensure the long-term sustainability of smallholder carbon projects, to administer BSM and can shape participants' abilities to draw an equitable share of benefits (Perez et al. 2007, Shames et al. 2012).

\subsection{Distributive equity}

The core parameters of distributive equity in certification schemes are the targeting, i.e. the selection of eligible beneficiaries and the distribution of costs and benefits (McDermott 2013). The decision of who should benefit can be based on different normative principles of distributive equity such as egalitarian, merit-based, need-based or libertarian (Pascual et al. 2010; Luttrell et al. 2013). Egalitarian equity principles demand equal sharing of total rewards among all providers of a service. Merit-based principles state that rewards shall be distributed proportional to contributions or inputs of stakeholders. This principle is widely established among Plan Vivo, CCB and Fairtrade, who require benefits to be distributed between the producers and project manager based on the incurred operational and transaction costs. Need-based principles state that benefits shall be distributed so that those with greatest need receive a higher reward. Libertarian principles demand that distribution of rewards should be based on the legal right to benefit. This is also reflected in Plan Vivo and Fairtrade; benefits are distributed to participating farmers with clear tenure rights. There is more detail information in Appendix 1 on type, timing and beneficiaries of benefits from case studies of each standard.

The distribution of costs and benefits are compared across the different schemes in Table 2. Valuable lessons for REDD+ can be drawn from Fairtrade, Plan Vivo and PGS on how they address the distributive equity with regard to: (1) cost assessment, (2) minimum payments, and (3) pre-financing.

\subsubsection{Cost assessment}

Assessing costs is important when designing a BSM to ensure beneficiaries receive net benefits (Luttrell et al. 2013). This has been done in existing FLO methodologies which calculate the "cost of sustainable production" (COSP) (Fairtrade International 2010). COSP data is obtained from a panel of producers using a consensus-building process. The producers are representatives of local farmers, chosen by local facilitators who are usually leaders of SPO (Fairtrade International 2010). The facilitators provide detailed farm operating information for a 1-year production period. Fairtrade uses the COSP data as key information for setting "Fairtrade minimum price", a mandatory payment from Fairtrade buyers made to farmers, accounting for the sustainable production costs (Fairtrade International 2010). A similar practice is run by PGS. In this case, all members of farmer group do an annual assessment to check whether their cost of production is still being covered. If it is no longer feasible or when there is a major change to production costs, then they can renegotiate with consumers (IFOAM 2005; Aliansi Organis Indonesia 2012).
Fairtrade methodologies for calculating COSP include implementation and transaction costs, and the latter includes costs of the intermediary and of certification (e.g. application fees, initial certification and follow-up audit fees) (Fairtrade International 2010). Fairtrade and PGS attempt to address costs changes through periodic reviews to ensure that the costs are covered. Research has found that the lack of information on how the costs are calculated and revised, and the price changes, might mean prices still fail to keep up with inflation (Bacon 2010). Such efforts from Fairtrade and PGS will include various implementation and transaction costs in setting a more equitable price, that are primarily determined by overall costsharing rather than dependence on the market alone.

Estimating the relevant implementation and transaction costs in Fairtrade is complex, and even more challenging in the case of REDD+, especially when opportunity costs need to be factored in. If REDD+ is similarly connected to a carbon market with the risk of price fluctuations, these examples provide a lesson on the importance of calculating incurred costs to ensure net benefits for producers, and of an equitable pricesetting mechanism between buyers and sellers. Opportunity costs, whilst not addressed by the standards, are also an important consideration in the REDD+ context.

\subsubsection{Minimum payment}

To ensure a more equitable payment, many of the standards have a guaranteed minimum payment to compensate for the implementation and transaction costs and to help producers mitigate market-related risks. Plan Vivo require a minimum of $60 \%$ of the total carbon finance generated go to communities, i.e. the implementers of the REDD+ activities (Table 2). Fairtrade farmers receive a minimum price set by the FLO; when a minimum price is below market price then buyers must still pay the higher price. On top of the minimum price, Fairtrade also requires buyers to pay a "Fairtrade premium" to farmers to ensure the development of common social goals of its members. Similarly in PGS, the inclusion of a minimum price ensures that the price offered to consumers reflects the real production costs taken on by the farmers. Figure 1 illustrates the Fairtrade prices (minimum price + premium) are well above the volatile world market prices in the case of Arabica coffee. If REDD+ is connected to the market mechanism, in which carbon offset prices are also extremely volatile, this financing option also gives us an insight on how to ensure sustainability of benefit flows and lower the price risks faced by the producers.

Unlike Fairtrade and PGS, producers in the CCB and FSC system are responsible for direct and indirect costs of certification. CCB has not yet shown that a price premium for carbon can ensure minimal social and environmental impacts (Diaz et al. 2011). For FSC-certified wood products there is also no consistent price premium, but there are other economic benefit from FSC certification, including easier market access (Taylor 2005). 


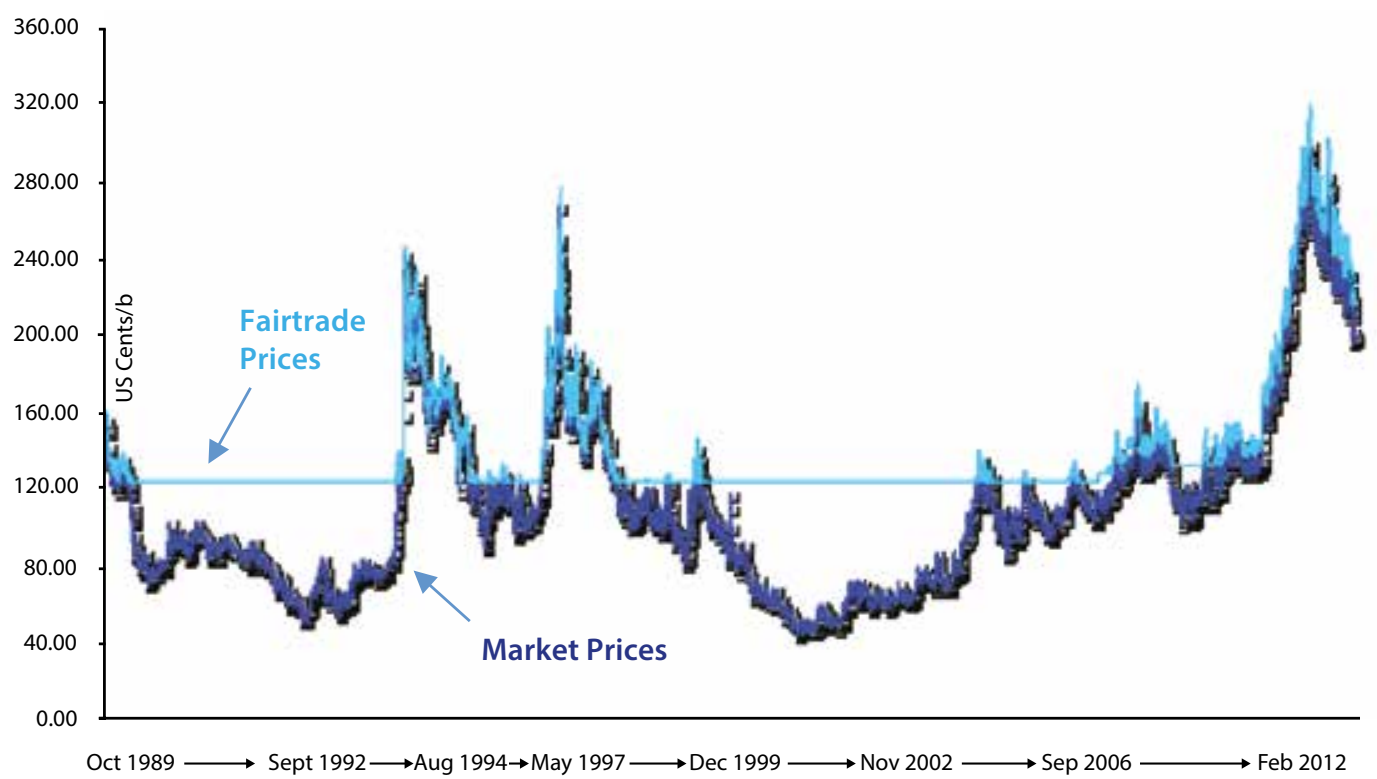

Figure 1. The Arabica coffee market 1989-2012: Comparison of Fairtrade and market prices.

Source: Fairtrade Foundation (2012)

Note: Fairtrade price in 2012= Fairtrade minimum price of 140 cents/lb + Fairtrade premium of 20 cents/lb;

If market price higher than minimum price, farmers receive market price plus Fairtrade premium.

Fairtrade premium is an attempt to extend Fairtrade impact by generating positive change at community level (Fairtrade International 2013). It cannot be used as a cash payment to individual producers; instead it must be invested in organizational development projects formulated in the development plan. Use of the premium should be decided democratically by the SPO and expenditure is accountable to FLO certification body. It is commonly invested for improvements in health care, education or other social facilities (e.g. micro-credit, funds and infrastructure), and may also be invested in certain development projects to enable producers to improve productivity and quality (Nelson and Pound 2009). A well-documented case study for premium utilization is from Cooperativa de Café (COOCAFE) in Costa Rica. COOCAFE invested $70 \%$ of the premium in a producers fund for micro-credit loans and 30\% was invested in the social capital fund used for capital acquisition and community investments (e.g. infrastructure for education and to increase productivity) (Ronchi 2002; Beyer 2008; Sáenz-Segura and Zúñiga-Arias 2009). The premium value can be relatively meager for individual producers, but the sum of money might be significant at a community level. This is an interesting insight for REDD+ - that in-kind collective benefits could be perceived as important as individual monetary benefits for communities - but this depends on the presence of strong, local institutions which serve the interest of the community members involved in the project (Howard et al. 2015).

While Fairtrade farmers receive on average higher prices for their produce, the implication on net income is less noticeable depending on the higher relative cost and benefit of certification (Ruben et al. 2009; Mendez et al. 2010; Ruben and Fort 2012). The effect of the minimum price is limited due to lack of demand and/or overabundance of Fairtrade products (Berndt 2007). On such occasions, farmers have been forced to sell their certified products as uncertified to the conventional market, so the payment had to be based on the conventional market prices (Mendez et al. 2010; Ruben and Fort 2012). Farmers therefore risk losing out on the expected benefits Fairtrade offers due to market uncertainties. For REDD+ carbon markets, the relative costs and benefits must be adequately accounted for to ensure participants are safeguarded against the unpredictability of markets.

\subsubsection{Pre-financing}

The timing in which the payment distribution takes place is also important for the participation of the vulnerable and marginalized groups. For example, in a carbon project known as Trees for Global Benefit (TGB) in Uganda verified by Plan Vivo, payments were only made after participants demonstrated commitment by planting after plan approval, thus favoring wealthier smallholders who are able to afford the seeds and the time (Peskett et al. 2011). Fairtrade, Plan Vivo and PGS also provide examples on how pre-financing to cover initial costs can encourage and support the participation of poor smallholders. In PGS, pre-financing is based on the agreement between consumers and farmers; consumers must provide finances to farmers before the start of the planting season (Willer et al. 2010).

In Fairtrade and Plan Vivo, the pre-financing is disbursed in phases based on meeting performance benchmarks. 
Table 2. The selected standards content on procedural, contextual and distributive equity.

\begin{tabular}{|c|c|}
\hline \multirow[t]{2}{*}{ Standards } & Aspects of equity in benefit-sh \\
\hline & Procedural \\
\hline $\begin{array}{l}\text { CCB } \\
\text { ( } 3^{\text {rd }} \text { edition) }\end{array}$ & $\begin{array}{l}\text { Require stakeholder } \\
\text { engagement through access } \\
\text { to information, consultation, } \\
\text { participation in decision- } \\
\text { making, implementation and } \\
\text { FPIC. }\end{array}$ \\
\hline
\end{tabular}

Plan Vivo Require active participation,

(2013 version) a community-led planning process and implementation.

Require FPIC before entering into project.

Fairtrade for Small Producer Organization (2011 version)

\section{Follow ILO recommendation} on promotion of cooperative. Require producer's organizations to have a democratic decision-making entity to ensure participation, transparency, empowerment and development for members.

FSC Require FPIC with local communities and indigenous peoples "affected" by forest management before achieving FSC.

\begin{tabular}{ll}
\hline PGS & Require active participation \\
& from all farmers within farmer \\
& group to decide on audit \\
& mechanism and proposed \\
& price for negotiation with \\
consumers.
\end{tabular}

\begin{tabular}{|c|c|}
\hline Contextual & Distributive \\
\hline $\begin{array}{l}\text { Require capacity building } \\
\text { efforts for project workers and } \\
\text { communities. }\end{array}$ & $\begin{array}{l}\text { Require that costs and benefits of implementation to be } \\
\text { equitably shared between communities and stakeholders } \\
\text { but do no specific guidance on distribution of cost/ }\end{array}$ \\
\hline Require FPIC where relocation & \\
\hline
\end{tabular}

Require FPIC where relocation will occur.

Reinforce legal requirements, including clarification on tenure rights.

Require capacity building for participants to enable them to develop a land management plan and monitoring.

Require clear land tenure for joining the project.

\section{Emphasis on smallholder} capacity building to achieve the goal of sustainable production system.
The gold level criteria target smallholder and communityled projects, requires equitable benefit distribution among its member.

Beneficiaries: the stakeholders defined as "communities". Require a fair and equitable benefit-sharing mechanism; with at least $60 \%$ of total sales to the participants and $40 \%$ to coordination, administration and monitoring costs. Require secure upfront funding; size and timing is flexible. Beneficiaries: communities and/or smallholders participating in the project.

Require buyers to pay a minimum price set by Fairtrade, aiming to cover costs of sustainable production (certification costs included); Fairtrade premium additional to the minimum price; pre-finance up to $60 \%$ by request. Beneficiaries: small producers participating in the project.

\section{Require to identify and uphold Require "community benefit", but do not address overal} indigenous peoples'legal and distribution of costs and benefits community rights of ownership, Beneficiaries: the forest enterprise, indigenous peoples, use and management of land local communities affected by management activities, and resources as defined in UN workers. Declaration on the Rights of Indigenous Peoples (UNDRIP) and ILO 169

Require capacity building Require agreement and negotiation with consumers on particularly in audit process and documentation to enable farmers to develop an audit mechanism plan. minimum price that covers production costs and profit margin for farmers. Require agreement among farmers within the farmers group regarding distribution of income to several cost components - cost for conducting peer review, management fee for farmers group, profit to be distributed among farmers.

Beneficiaries: participating organic farmers.

Source: Fonseca et al. (2008); May (2008); Fairtrade International (2011); FSC (2012); CCBA (2013); Plan Vivo Foundation (2013)

For example in Fairtrade, COOCAFE partially finances the producers at three intervals: (i) pre-harvest, to buy inputs for production; (ii) during harvest time; and (iii) when the final liquidation is announced and the SPO must pay its members fully (Lawson 2004). The first installment from COOCAFE facilitates entry of both farmers and poor landowners to the program (Beyer 2008). The periodical payments to partly cover the implementation and transaction costs provide both the SPO and the producers with needed stability and security (Lawson 2004; Walsh 2004; Beyer 2008). Overall pre-financing can be a strong motivator and facilitator for project participants to meet project objectives. However phased payments may still risk jeopardizing the expected project results if they are not carefully considered in accordance with the aim and lifetime of the project. In the same Plan Vivo TGB project in Uganda for example, producers received pre-financing in five installments within 10 years, based upon certain performances, over the course of a 25-year contract. This means that producers will have no financial incentives and sanction in the final 15 years of their contract. The project may fail to achieve its expected results without having sustained incentives (Wunder et al. 2008; Peskett et al. 2011).

Phased-released pre-financing requirements of the standards provide clear insights for REDD+ for enhancing the ability of marginalized and poor stakeholders to participate in the initiative that otherwise may not have been financially possible. This is an important contribution for producers to partially cover the burden of investment costs and further account for livelihood needs and preference, but outcomes depend on how these are devised and which conditions are placed on the finance (Howard et al. 2015). Furthermore, by providing negotiated phased payments can strengthen the effectiveness of initiatives by providing a continuous cash flow to support performance delivery. 


\section{Conclusion}

Overall, the reviewed certification standards (CCB, Fairtrade on SPO, Plan Vivo, and FSC) and PGS reveal many lessons for the development of equitable REDD+ BSMs. Through the analytical lens of procedural, contextual and distributive equity, we have demonstrated that all of the standards reviewed aim to address equity issues in their implementation, yet definitions of what is meant by equity and how it will be achieved are lacking.

Furthermore, the three equity dimensions are addressed to varying extents by each of the selected standards. Valuable lessons from Fairtrade on SPO, Plan Vivo and PGS dominate in procedural and distributive equity. FSC focuses more on procedural and contextual equity for indigenous people and local communities providing lesson on how to create enabling conditions for distributive equity. CCB key lessons reflect procedural equity; emphasizing and facilitating participation from wider relevant stakeholders. Below are the key lessons for enhancing equitable REDD+ BSM through procedural, contextual and procedural equity that are interdependent.

Lessons for REDD+ to enhance procedural equity:

- Participation should be clearly defined so that the best tools (FPIC, access to information, consultation, participation in decision making and implementation) can reach the targeted stakeholder groups to achieve the stated objectives (e.g. mitigate possible negative impact, improve livelihood).

- Local participation could work better and be more meaningful with the presence of strong local intermediary institutions. Hence, local level support and capacity building are needed to strengthen institutions in order to improve governance and increase legitimacy in decision-making on how benefits are shared.

- Mandatory systematic measures to identify marginalized groups and to support increasing levels of their participation in the design, implementation and monitoring of REDD+ activities and the BSM is crucial for the effectiveness of REDD+ and avoid perpetuating existing inequality. More stringent procedural equity measures will lead to increased costs and a trade-off between equity and efficiency.

- A more effective dispute-resolution mechanism should be clear and concise (i.e. avoid legal terms and complex procedures) making the process more accessible to local individuals and small organizations. Acknowledge and incorporate traditional methods and culturally appropriate ways for handling and resolving disputes.

Lessons to enhance contextual equity:

- Increase the capacity of REDD+ stakeholders, via local institutions, to implement REDD+ activities; to support design and administration of a benefit-sharing mechanism; and to participate and negotiate in decisionmaking processes.
- $\quad$ Proper implementation of FPIC processes, which has become a central principle of REDD+ social safeguards, can increase actor's capacities to negotiate and secure local rights to resources.

Lessons to enhance distributive equity:

- Include robust calculations of REDD+ implementation, transaction and opportunity costs as a basis for more equitable price setting to ensure that suppliers of reduced carbon emissions receive payments that at least compensate for the costs they bear.

- Creation of social benefits at the community level can be an important incentive, and one option in how REDD+ benefits can be delivered. In addition, REDD+ safeguards should also consider delivery of community-level co-benefits from REDD+ initiatives.

- Provide pre-financing for participating stakeholders, which could be particularly important to enable poorer stakeholders to participate in REDD+ implementation activities. Pre-financing can help to mitigate market and other risks and raises project acceptance. Phased-released benefits also may strengthen conformity to conditional performance, creating a balance to ensure that incentives are maintained throughout the project lifetime.

\section{Acknowledgments}

The authors gratefully acknowledge funds received from the European Commission, NORAD, Ausaid and UK aid. We are also grateful to Cecilia Luttrell for her substantive input in framing the review of the topic, and to Lasse Loft, Grace Wong and Tim Cronin, whose critical remarks have helped to improve the article.

\section{References}

Aliansi Organis Indonesia. 2012. Panduan Penjaminan Berbasis Komunitas di Indonesia. Internal Publication.

Amerasinghe M, Farrell L, Jin S, Shin N-Y and Stelljes K. 2008. Enabling environmental justice: Assessment of participatory tools. Cambridge, MA: Massachusetts Institute of Technology.

Assembe-Mvondo S, Brockhaus M and Lescuyer G. 2013. Assessment of the effectiveness, efficiency and equity of benefit-sharing schemes under large-scale agriculture: Lessons from land fees in Cameroon. European Journal of Development Research 25(4):641-56.

Bacon CM. 2010. Who decides what is fair in fair trade? The agrienvironmental governance of standards, access, and price. Journal of Peasant Studies 37(1):111-47.

Berndt CEH. 2007. Is fair trade in coffee production fair and useful? Evidence from Costa Rica and Guatemala and implications for policy. P.C. Mercatus 65 Policy Series. Washington, DC: Mercatus Centre, George Mason University.

Beyer J. 2008. The impacts of fairtrade coffee in producer countries. Ottawa, Ontario: Department of Economics, Carleton University.

Blomley T and Richards M. 2011. Community engagement guidance: Good practice for forest carbon projects. In Ebeling J and Olander J, eds. Building Forest Carbon Projects. Washington, DC: Forest Trends. 
[CCBA] The Climate, Community \& Biodiversity Alliance. 2013. Climate, Community \& Biodiversity Standards. 3rd ed. Arlington, VA.

[CCBA] The Climate, Community \& Biodiversity Alliance. 2011. About the Climate, Community \& Biodiversity Alliance. Accessed 25 March 2015. http://www.climate-standards.org/about-ccba/

Cerutti PO, Lescuyer G, Tsanga R, Kassa SN, Mapangou PR, Mendoula EE, Missamba-Lola AP, Nasi R, Eckebil PPT and Yembe RY. 2014. Social impacts of the forest stewardship council certification: An assessment in the Congo Basin. Occasional Paper 103. Bogor, Indonesia: Center for International Forestry Research.

Colchester M, Sirait M and Wijardjo B. 2003. Obstacles and possibilities: The application of FSC principles $2 \& 3$ in Indonesia. Report published by WAHLI and AMAN.

Costenbader J. 2011. REDD+ benefit sharing: A comparative assessment of three national policy approaches. UN-REDD Programme.

Counsell S and Terje Loraas K. 2002. Trading in creadibility: The myth and reality of the forest stewardship council. London: The Rainforest Foundation.

Di Gregorio M, Brockhaus M, Cronin T, Muharrom E, Santoso L, Mardiah S and Büdenbender M. 2013. Equity and REDD+ in the media: A comparative analysis of policy discourses. Ecology and Society 18(2):39.

Diaz D, Hamilton K and Johnson E. 2011. State of the forest carbon market 2011: From canopy to currency. Ecosystem Marketplace. Forest Trends.

Dyer GA, Matthews R and Meyfroidt P. 2012. Is there an ideal REDD+ program? An analysis of policy trade-offs at the local level. PloS ONE 7(12):e52478.

Earle A and Malzbender D. 2006. Stakeholder Participation in Transboundary Water Management - Selected Case Studies. Cape Town, South Africa: African Centre for Water Research.

Eklöf G. 2013. REDD plus or REDD "light"? - Biodiversity, communities and forest carbon certification. Stockholm, Sweden: Swedish Society for Nature Conservation.

Fairtrade Foundation. 2012. Fairtrade and coffee: Commodity briefing. Fairtrade Foundation.

Fairtrade International 2013. Monitoring the scope and benefits of fairtrade. 5th ed. Bonn, Germany: Fairtrade International.

Fairtrade International 2011. Fairtrade standard for small producer organizations. Bonn, Germany: Fairtrade International.

Fairtrade International 2010. Guideline for estimating costs of sustainable production. Bonn, Germany: Fairtrade International.

[FAO] Food and Agriculture Organization of the United Nations. 2003. Environmental and social standards, certification and labelling for cash crops. Rome: FAO.

Fonseca MF, Wilkinson J, Egelyng H and Mascarenhas G. 2008. The institutionalization of participatory guarantee systems (PGS) in Brazil: Organic and fair trade initiatives. 16th IFOAM Organic World Congress. Modena, Italy.

[FSC] Forest Stewardship Council. 2012a. FSC Principles and Criteria for Forest Stewardship, FSC-STD-01-001 V5-0 EN. Bonn, Germany: FSC

[FSC] Forest Stewardship Council. 2012b. FSC guidelines for the implementation of the right to free, prior and informed consent (FPIC) Version 1. Bonn, Germany: FSC.

[FSC] Forest Stewardship Council. 2009. FSC Dispute Resolution System FSC-STD-01-005 (V1-0) EN. Bonn, Germany: FSC.

Gebara MF. 2013. Importance of local participation in achieving equity in benefit-sharing mechanisms for REDD+: A case study from the Juma sustainable development reserve. International Journal of the Commons 7(2):473-497.

Howard RJ, Tallontire A, Stringer L and Marchant R. 2015. Unraveling the notion of "fair carbon": Key challenges for standards development. World Development 70:343-56.

[IFOAM] International Federation of Organic Agriculture Movements. 2005. Study: Participatory Guarantee Systems (PGS) Case study in Brazil, India, New Zealand and USA. IFOAM.

Lawlor K, Madeira EM, Blockhus J and Ganz DJ. 2013. Community participation and benefits in REDD+: A review of initial outcomes and lessons. Forests 4(2): 296-318.

Lawson J. 2004. Promoting sustainable livelihoods through trade: Fair trade as a vehicle for economic, social, and environmental sustainability in coffee production in Coto Brus, Costa Rica. [Doctoral thesis]. Washington DC: Georgetown University.

Le Mare A. 2008. The impact of fair trade on social and economic development: A review of the literature. Geography Compass 2(6):1922-42.

Luttrell C, Loft L, Gebara MF, Kweka D, Brockhaus M, Angelsen A and Sunderlin WD. 2013. Who should benefit from REDD+? Rationales and realities. Ecology and Society 18(4):52.

McDermott CL. 2013. Certification and equity: Applying an equity framework to compare certification schemes across product sectors and scales. Environmental Science \& Policy 33:428-37.

McDermott M, Mahanty S and Schreckenberg K. 2013. Examining equity: A multidimensional framework for assessing equity in payments for ecosystem services. Environmental Science \& Policy 33:416-27.

McDermott M, Mahanty S and Schreckenberg K. 2011. Defining equity: A framework for evaluating equity in the context of ecosystem services. http://www.espa.ac.uk/files/espa/ Schreckenberg-poster.pdf

Marx A, Becault E and Wouters J. 2012. Private standards in forestry: Assessing the legitimacy and effectiveness of the Forest Stewarship Council. In Marx A, Maertens M, Swinnen J and Wouters J, eds. Private Standards and Global Governance: Economic, Legal and Political Perspectives. Cheltenham, UK: Edward Elgar Publishing. 60-97.

May C. 2008. PGS guidelines: How participatory guarantee systems can develop and function. Bonn, Germany: IFOAM.

Mendez VE, Bacon CM, Olson M, Petchers S, Herrador D, Carranza C, Trujillo L, Guadarrama-Zugasti C, Cordon A and Mendoza A. 2010. Effects of fair trade and organic certifications on smallscale coffee farmer households in Central America and Mexico. Renewable Agriculture and Food Systems 25(03):236-51.

Mendoza R and Bastiaensen J. 2003. Fair trade and the coffee crisis in the Nicaraguan segovias. Small Enterprise Development 14(2):36-46.

Nelson $V$ and Pound B. 2009. The last ten years: A comprehensive review of the literature on the impact of Fairtrade. University of Greenwich, Greenwich UK: Natural Resources Institute.

Pascual U, Muradian R, Rodríguez LC and Duraiappah A. 2010. Exploring the links between equity and efficiency in payments for environmental services: A conceptual approach. Ecological Economics 69(6):1237-44.

Perez C, Roncoli C, Neely C and Steiner JL. 2007. Can carbon sequestration markets benefit low-income producers in semiarid Africa? Potentials and challenges. Agricultural Systems 94(1):2-12.

Peskett L, Schreckenberg K and Brown J. 2011. Institutional approaches for carbon financing in the forest sector: learning 
lessons for REDD+ from forest carbon projects in Uganda. Environmental Science \& Policy 14(2):216-29.

Pimbert MP and Pretty JN. 1995. Parks, people and professionals: Putting "participation" into protected area management. UNRISD.

Plan Vivo Foundation. 2013. The Plan Vivo standard: For community payments for ecosystem services programmes.

Plan Vivo Foundation. 2012. Plan Vivo guidance manual for designing and implementing payments for ecosystems services programmes with rural communities. Plan Vivo Foundation.

Ronchi L. 2002. The impact of fair trade on producers and their organizations: A case study with COOCAFÉ in Costa Rica. Prus Working Paper No. 11. Brighton, UK: Poverty Research Unit, University of Sussex.

Rosendal GK. 2010. Access to and benefit sharing of genetic resources in Cameroon: Legal and institutional developments and challenges. Lysaker, Norway: Fridtjof Nansen Institute (FNI).

Ruben R and Fort R. 2012. The impact of fair trade certification for coffee farmers in Peru. World Development 40(3):570-82.

Ruben R, Fort R and Zúñiga-Arias G. 2009. Measuring the impact of fair trade on development. Development in Practice 19(6):777-88.

Sáenz-Segura F and Zúñiga-Arias G. 2009. Assessment of the effect of fair trade on smallholder producers in Costa Rica: A comparative study in the coffee sector. In Ruben R. The Impact of Fair Trade. Wageningen, The Netherlands: Wageningen Academic Publisher.

Schreckenberg K. 2012. Safeguard local equity as global values of ecosystem services rise. UN Development Information Day.

Setyowati A. 2012. Ensuring that women benefit from REDD+. Unasylva 239(63):57-62.

Shames S, Wollenberg E, Buck LE, Kristjanson P, Masiga M and Biryahwaho B. 2012. Institutional innovations in African smallholder carbon projects. Copenhagen, Denmark: CGIAR Research Program on Climate Change, Agriculture and Food Security (CCAFS).

Shrader-Frechette KS. 2002. Environmental Justice: Creating Equality, Reclaiming Democracy. New York: Oxford University Press.
Simula M, Astana S, Ishmael R, Santana EJ and Schmidt ML. 2004. Report on financial cost-benefit analysis of forest certification and implementation of phased approaches. Yokohama, Japan: International Tropical Timber Organization.

Smith S. 2010. Fairtrade bananas: A global assessment of impact. Sussex, UK: Institute of Development Studies, University of Sussex.

Sommerville M, Jones JPG, Rahajaharison M and Milner-Gulland EJ. 2010. The role of fairness and benefit distribution in community-based payment for environmental services interventions: A case study from Menabe, Madagascar. Ecological Economics 69(6):1262-71.

Synnott T. 2012. Report on motion 20 on large operations and motion 21 on plantation policy. Prepared for the Forest Stewardship Council, IC. Saltillo, Mexico.

Taylor PL. 2005. In the market but not of it: Fair trade coffee and forest stewardship council certification as market-based social change. World Development 33(1):129-47.

Utting K. 2009. Assessing the impact of fair trade coffee: Towards an integrative framework. Journal of Business Ethics 86(1):127-49.

Vhugen D, Aguilar S and Miner J. 2011. REDD+ and carbon rights: Lesson from the field. Property Rights and Resource Governance Project (PRRGP). Washington, DC: USAID.

Walsh JM. 2004. Fair trade in the fields: Outcomes for Peruvian coffee products. [Doctoral thesis]. Cambridge, MA: Massachusetts Institute of Technology.

Willer H, Yussefi-Menzler M and Sorensen N, eds. 2010. The world of organic agriculture: Statistics and emerging trends 2008. Bonn, Germany: International Federation of Organic Agriculture Movements (IFOAM) and Frick, Switzerland: Research Institute of Organic Agriculture (FiBL).

Wunder S, Engel S and Pagiola S. 2008. Taking stock: A comparative analysis of payments for environmental services programs in developed and developing countries. Ecological Economics 65(4): 834-52.

Yang AL, Rounsevell MDA, Haggett C and Wilson RM. 2014. Recentralisation through regionalisation in the implementation of rural development policy in Scotland. Journal of Environmental Planning and Management.

\section{Appendix 1. Type, timing, and beneficiaries of benefits from case studies}

\begin{tabular}{|c|c|c|c|c|}
\hline Case Study & Intermediary & Benefit Type & Disbursement Interval & Beneficiary \\
\hline Fairtrade & \multirow[t]{4}{*}{ SPO COOCAFE } & \multirow{3}{*}{$\begin{array}{l}\text { Direct: cash payments, strengthened } \\
\text { the producer organizations (capacity } \\
\text { building); in-kind benefits from } \\
\text { Fairtrade premium investment: micro- } \\
\text { credit loans, capitalization funds, } \\
\text { scholarship and infrastructure for } \\
\text { education and to improve productivity. }\end{array}$} & \multirow{4}{*}{$\begin{array}{l}\text { Operational costs of the } \\
\text { farmer's organization is } \\
\text { deducted from the cash } \\
\text { payment. Received pre-finance } \\
\text { from buyers and loans from } \\
\text { banks to fully finance the } \\
\text { production. Phased pre- } \\
\text { financing: (1) pre-harvest so } \\
\text { farmers can buy inputs for the } \\
\text { coffee, (2) harvest time at the } \\
\text { recollection of the coffee, and } \\
\text { (3) when the final liquidation } \\
\text { is announced and the farmers } \\
\text { receive full payment. }\end{array}$} & $\begin{array}{l}\text { The producers, member of } \\
\text { SPO. }\end{array}$ \\
\hline \multirow[t]{3}{*}{$\begin{array}{l}\text { COOCAFE, } \\
\text { Costa Rica }\end{array}$} & & & & $\begin{array}{l}\text { SPO. } \\
\text { Farmers have to have secure } \\
\text { tenure either individually } \\
\text { owned or communal land. }\end{array}$ \\
\hline & & & & Beneficiaries are based on \\
\hline & & $\begin{array}{l}\text { Indirect: increased income averaged } \\
39 \% \text { higher than non-Fairtrade farmers, } \\
\text { better represented at the community } \\
\text { and national level, better access to } \\
\text { external funds (bank loan). }\end{array}$ & & principles. \\
\hline FSC & \multirow{2}{*}{$\begin{array}{l}\text { Certification } \\
\text { holder (Forestry } \\
\text { Department) }\end{array}$} & Direct: occasional job (tree planning), & \multirow[t]{2}{*}{ Phased-released } & \multirow{2}{*}{$\begin{array}{l}\text { Beneficiaries are based on } \\
\text { libertarian principles. }\end{array}$} \\
\hline $\begin{array}{l}\text { Forestry } \\
\text { Department; } \\
\text { Malaysia }\end{array}$ & & $\begin{array}{l}\text { construction of community } \\
\text { pipe gravity water system and } \\
\text { kindergarden, transportation }\end{array}$ & & \\
\hline
\end{tabular}




\section{Appendix 1. Continued}

\begin{tabular}{lll}
\hline Case Study & Intermediary & Benefit Type \\
\hline CCB & A for-profit & $\begin{array}{l}\text { Direct: cash payment, capacity building } \\
\text { (training on climate change, HIV/AIDS, }\end{array}$ \\
$\begin{array}{l}\text { The International } \\
\text { Small Group }\end{array}$ & $\begin{array}{l}\text { United State } \\
\text { corporation, }\end{array}$ & $\begin{array}{l}\text { biodiversity, conservation farming), } \\
\text { fuel efficient stoves, benefits of trees }\end{array}$ \\
$\begin{array}{l}\text { Tree Planting } \\
\text { Program (TIST), }\end{array}$ & $\begin{array}{l}\text { Corpon Air Action } \\
\text { (fuelwood, fruits, nuts, fodder) }\end{array}$ \\
Kenya & (CAAC) & $\begin{array}{l}\text { Indirect: increased corn yield using } \\
\text { conservation farming practices, new } \\
\text { source of income (from selling tree } \\
\text { products) }\end{array}$
\end{tabular}

\begin{tabular}{ll}
\hline Plan Vivo & NGO The \\
The Trees For & Environmental \\
Global Benefits & Conservation \\
project, Uganda & Trust of Uganda \\
& (ECOTRUST)
\end{tabular}

\begin{tabular}{lll} 
& & $\begin{array}{l}\text { controlling for erosion and siltation of } \\
\text { rivers). } \\
\text { Indirect: improved financial } \\
\text { management (e.g. the development of } \\
\text { village banks run by the communities), } \\
\text { better access to loan (from village banks) }\end{array}$ \\
\hline $\begin{array}{l}\text { PGS farmers group } \\
\text { in Boyolali district, } \\
\text { Indonesia }\end{array}$ & $\begin{array}{l}\text { A local NGO } \\
\text { Lembaga Studi } \\
\text { Kemasyarakatan } \\
\text { dan Bina Bakat } \\
\text { (LSKBB) }\end{array}$ & $\begin{array}{l}\text { Direct: cash payment (higher price } \\
\text { received compare to non-organic } \\
\text { farmers), market guarantee }\end{array}$ \\
\hline & &
\end{tabular}
management), land tenure security,

\section{Disbursement Interval Beneficiary}

The producers of carbon organized through farmers group.

each year on the basis of the number of quantified trees (trees at least 6 months old). Individual project areas are Additionally, when TIST Kenya either owned by the small revenues exceed costs, farmers group member/farmer, a will receive $70 \%$ of profits. family member of the small group member, or with permission of the landowner.

Beneficiaries are based on merit-based principles.

The producers of carbon organized through farmers associations. Communities/ farmers under customary 25 year project period): Year 0: $50 \%$ plot planted; $30 \%$ carbon value. Year 1: $100 \%$ plot tenure, individual farmers/ planted, $20 \%$ payment. Year private landowners. 3: survival not less than $85 \%$, Beneficiaries are based on DBH not less than $10 \mathrm{~cm} ; 10 \%$ principles. payment. Year 10.

\begin{tabular}{|c|c|}
\hline $\begin{array}{l}\text { Result-based. Farmers get the } \\
\text { payment for production cost } \\
\text { plus profit. Peer review and } \\
\text { management fee are deducted } \\
\text { from the total payment. }\end{array}$ & $\begin{array}{l}\text { Farmers who are member of } \\
\text { the farmers' group. } \\
\text { Beneficiaries are based on } \\
\text { merit-based principles. }\end{array}$ \\
\hline
\end{tabular}

This info brief is part of a series of reviews on existing literature and practices to derive relevant lessons for the design of REDD+ benefit sharing mechanisms. The reviews aim to stimulate debate on balancing effectiveness and efficiency, while ensuring equity in ongoing policy processes in the development of REDD+ as a performance-based mechanism.

\begin{tabular}{|c|c|c|}
\hline CGIAR & $\begin{array}{l}\text { RESEARCH } \\
\text { PROGRAM ON } \\
\text { Forests, Trees and } \\
\text { Agroforestry }\end{array}$ & $\begin{array}{l}\text { This research was carried out by CIFOR as part of the CGIAR Research Program on Forests, Trees and } \\
\text { Agroforestry (CRP-FTA). This collaborative program aims to enhance the management and use of } \\
\text { forests, agroforestry and tree genetic resources across the landscape from forests to farms. CIFOR } \\
\text { leads CRP-FTA in partnership with Bioversity International, CATIE, CIRAD, the International Center for } \\
\text { Tropical Agriculture and the World Agroforestry Centre }\end{array}$ \\
\hline
\end{tabular}
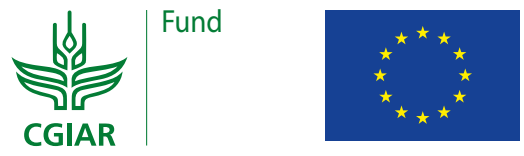

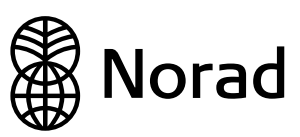

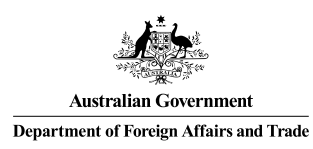

\section{Australian Aid}

